\title{
A Dor durante a Punção do Canal Vertebral e sua Relação com a Inervação do Ligamento Amarelo, da Dura-Máter e do Ligamento Longitudinal Posterior *
}

\author{
Pain during Spinal Canal Puncture and its Relationship with Ligamentum \\ Flavum, Dura-Mater and Posterior Longitudinal Ligament Innervation
}

\author{
Edmundo Zarzur, TSA ${ }^{1}$
}

\begin{abstract}
RESUMO
Zarzur E - A Dor durante a Punção do Canal Vertebral e sua Relação com a Inervação do Ligamento Amarelo, da Dura-Máter e do Ligamento Longitudinal Posterior
\end{abstract}

\begin{abstract}
JUSTIFICATIVA E OBJETIVOS: A dor durante a punção raquidiana é um sinal de alarme, indicando que a ponta da agulha tocou numa estrutura nervosa. Por este motivo, se o paciente acusar dor durante a punção, é obrigatória a interrupção da técnica. A solução anestésica não deverá ser injetada para evitar uma possível lesão de raiz nervosa ou da medula espinhal. Deve-se recuar a agulha e mudar sua direção antes de novo avanço. O relato de dor é totalmente impossivel se o paciente estiver adormecido sob influência da anestesia geral e, por este motivo, é recomendável que bloqueios sejam realizados com o paciente consciente. A dor só é referida quando a ponta da agulha ou a ponta do cateter desviarem-se do plano médio sagital para atingir o compartimento peridural ântero-lateral, podendo, desta forma tocar as radículas nervosas situadas próximas aos forames intervertebrais. Excluindo-se os estudos sobre a inervação da pele, do tecido celular subcutâneo e do ligamento interespinhoso, o objetivo deste trabalho é o de rever a inervação de algumas estruturas do canal vertebral: do ligamento amarelo, do ligamento longitudinal posterior, da dura-máter e do disco intervertebral.
\end{abstract}

CONTEÚDO: Estudos sobre a inervação do canal vertebral serão apresentados nesta revisão da literatura, com a intenção punção do canal raquidiano.

CONCLUSÕES: O ligamento amarelo é desprovido de inervação, explicando a ausência de dor durante a sua punção. Outras dores, durante a punção, podem ser atribuídas ao nervo de Luschka que inerva o ligamento longitudinal posterior e a

Unitermos: COMPLICAÇÕES: dor; INERVAÇÃO DO CANAL VERTEBRAL; TÉCNICAS ANESTÉSICAS, Regional: peridural, subaracnóidea

\footnotetext{
* Recebido do (Received from) CET em Anestesiologia da Santa Casa de Misericórdia de São Paulo

1. Co-responsável do CET em Anestesiologia da Santa Casa de Misericórdia de São Paulo
}

Apresentado (Submitted) em 04 de fevereiro de 2004

Aceito (Accepted) para publicação em 18 de maio de 2004

Endereço para correspondência (Correspondence to)

Dr. Edmundo Zarzur

Rua Ziembinski, 314

05086-020 São Paulo, SP

(c) Sociedade Brasileira de Anestesiologia, 2004 de procurar entender a razão da origem da dor durante a porção ventral da dura-máter.

\section{SUMMARY}

Zarzur E - Pain during Spinal Canal Puncture and its Relationship with Ligamentum Flavum, Dura-Mater and Posterior Longitudinal Ligament Innervation

BACKGROUND AND OBJECTIVES: Pain during spinal puncture is a warning that needle tip has touched a nervous structure. If patients refer pain during puncture, it is mandatory to interrupt the technique. Anesthetic solution should not be injected to prevent potential nervous root or spinal cord injury. Needle should be drawn back and have its direction changed before a new advance is attempted. Pain complain is totally impossible if patients are asleep under the influence of general anesthesia and that is why blockade with conscious patients is advisable. Pain is only referred when needle or catheter tip bypass the medium sagital plane to reach the antero-lateral epidural compartment, thus being able to touch nervous rootlets close to intervertebral foramina. Except for studies on skin, subcutaneous tissue and interspinous ligament innervation, this study aimed at reviewing the innervation of some spinal canal structures, namely, ligamentum flavum, posterior longitudinal ligament, dura-mater and intervertebral disk.

CONTENTS: Studies on spinal canal innervation are presented in this literature review, aiming at understanding pain during spinal puncture.

CONCLUSIONS: Ligamentum flavum is not innervated, thus explaining lack of pain during puncture. Other pains during puncture may be attributed to Luschka's nerve, which innervates posterior longitudinal ligament and dural ventral portion.

Key Words: ANESTHETIC TECHNIQUES, Regional: epidural, spinal block

\section{INTRODUÇÃO}

$\mathrm{N}$ o espaço subaracnóideo, além do líquor, temos as raízes nervosas e a medula espinhal. A raiz ventral ou motora tem seus neurônios na substância cinzenta do funículo anterior da medula. Em cada segmento da coluna vertebral estes neurônios motores formam quatro ou cinco radículas que se juntam originando a raiz anterior que, após atravessar o espaço subaracnóideo, perfura o saco dural e, envolvida pela dura-máter, caminha ao lado do gânglio da raiz dorsal. A raiz dorsal ou sensitiva tem seus neurônios no gânglio da raiz dorsal, passa pela dura-máter e atravessa o espaço subaracnóideo para, nas proximidades da medula, dividir-se em seis radículas antes de penetrar no funículo posterior da medula. 
Como se pode concluir, estas raízes ventrais e dorsais só transitam pelo espaço subaracnóideo e, portanto, não são responsáveis pela inervação de estruturas do canal vertebral.

O objetivo deste trabalho é rever a inervação das estruturas que estão envolvidas na punção peridural e/ou subaracnóidea, advertindo para possíveis complicações quando o paciente refere dor durante o procedimento.

\section{HISTÓRICO}

Vários cientistas estudaram a inervação do canal vertebral. O ligamento amarelo é desprovido de inervação, explicando a ausência de dor durante a sua punção ${ }^{1}$. Luschka, em 1850 , foi quem pela primeira vez descreveu um ramo recorrente meníngeo reconhecido atualmente como sendo o responsável pela inervação de várias estruturas do canal vertebral ${ }^{2}$.

O nervo de Luschka é o primeiro ramo originado do nervo raquidiano. Logo após sair do forame intervertebral o nervo raquídeo fornece um primeiro ramo que passa pelo forame intervertebral e, voltando para o canal, junto com um ramo comunicante cinzento do simpático, distribui-se mediante filetes muito delgados, pelo disco intervertebral, em ligamentos longitudinais anterior e posterior e pela porção ventral da dura-máter.

Groen e col. dissecaram as colunas vertebrais de vários fetos com a finalidade de estudar a inervação da dura-máter. Após a retirada das meninges torácicas, os plexos nervosos foram corados e fotografados por um processo de transiluminação ${ }^{3}$.

Verificaram que o nervo recorrente de Luschka forma um extenso plexo nervoso sobre o ligamento longitudinal posterior e sobre a porção ventral da dura-máter, ficando sem inervação a face dorsal do saco dural. Portanto, recebem fibras sensitivas fornecidas pelo nervo de Luschka somente a dura-máter ventral, a dura-máter que envolve as raízes nervosas após deixarem o saco dural e o ligamento longitudinal posterior (Figura 1).

Fica sem inervação a face dorsal da dura-máter, o que explica a ausência de dor ao ser puncionada. Raoul e col. ${ }^{4}$ também estudaram o nervo recorrente meníngeo de seis cadáveres frescos e três formolizados. No entanto, suas observações foram dirigidas para o canal vertebral lombar. Verificaram que o nervo de Luschka, acompanhado de um ramo comunicante simpático, voltava para dentro do canal para inervar o disco intervertebral, a face ventral da dura-máter e os ligamentos longitudinais anterior e posterior. Concluíram que as dores da coluna vertebral podem ter relação com esta inervação, e que infiltrações do espaço peridural com soluções anestésicas podem ser usadas para o alívio das dores. Pelo fato da dura-máter ventral ser inervada, Cyriax admitiu que sua compressão por uma hérnia de disco pode provocar intensa dor lombar aguda ${ }^{5}$. Neste caso, o tratamento com

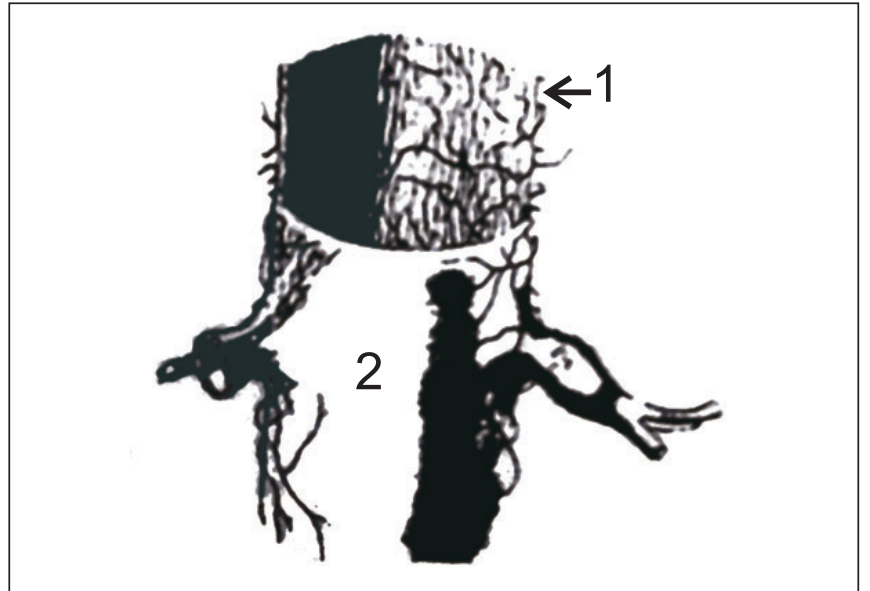

Figura 1 - Desenho Esquemático mostrando a Inervação da Dura-Máter

Visão dorsal do cilíndrico saco dural com os seus manguitos. 1- Plexo nervoso da porção ventral da dura-máter; 2- Porção dorsal da dura-máter. Não são mostrados os ramos do nervo de Luschka e o plexo nervoso do ligamento longitudinal posterior

anestesia peridural causa um efeito dramático, aliviando a dor em poucos minutos.

É evidente que após a perfuração da dura-máter pode ocorrer dor na região lombar por lesão de radículas nervosas e na região torácica, por lesão direta da medula espinhal.

Assim, a queixa de dor referida durante uma punção raquidiana deve ser atribuída ao desvio da direção (plano médio sagital) que a agulha deveria seguir. Deve-se lembrar de que a dor pode ocorrer durante a técnica do bloqueio peridural em dose única. Na perspectiva de comprovar esta tese, Mondadore injetava água destilada para a confirmação da correta localização da agulha no espaço peridural ${ }^{6}$. Ainjeção de três a quatro $\mathrm{ml}$ de água destilada no espaço peridural provocava dor. Era "A Prova da Dor", considerada, por ele, muito mais freqüente do que o sinal da aspiração da gota. Posteriormente, esta prática foi abandonada por provocar dor muito intensa e não suportável pelo paciente. No entanto, a água destilada injetada no espaço subaracnóideo não provocava dor e nenhuma outra sensação. Mondadore não encontrou razões de ordem anatômica para a explicação do aparecimento da dor no espaço peridural.

Zarzur e col. constataram que a "dose-teste", quando realizada com solução anestésica contendo adrenalina, provocava dor perfeitamente suportável ${ }^{7}$. Esta dor seria uma confirmação da localização da ponta da agulha no espaço peridural. Já uma segunda dose-teste não provocava dor. Verificaram também que a dose-teste quando realizada com solução anestésica sem adrenalina não causava dor. Provavelmente a dor poderia ser atribuída a uma sensibilidade especial da dura-máter, devido ao baixo pH da solução anestésica contendo adrenalina. Na época em que foi publicado o trabaIho a respeito da dor da dose-teste, não se tinha idéia da razão da falta de dor durante a segunda dose-teste. Com os co- 
nhecimentos atuais pode-se afirmar que a primeira dose-teste bloqueia as terminações nervosas, justificando a ausência de dor quando da segunda dose-teste.

Deve-se lembrar que parestesias ou dores durante a introdução do cateter, pela técnica do bloqueio peridural contínuo, são provas da má localização da ponta do cateter que pode estar tocando raízes nervosas localizadas no compartimento peridural ântero-lateral, portanto, nas proximidades dos forames intervertebrais. Como os cateteres atualmente utilizados não perfuram a dura-máter ${ }^{8} \mathrm{e}$, quando introduzidos no espaço peridural por dois ou mais centímetros, avançam acompanhando a curvatura do saco dural, podem atingir a raiz dorsal localizada no compartimento peridural ântero-lateral.

Nestes casos pode haver uma alta incidência de falhas ou um bloqueio de distribuição unilateral e insatisfatório . Hehre e col. ${ }^{9}$ citaram que sete de dezesseis falhas de bloqueios peridurais foram precedidas por parestesias. Para Sanches e col. ${ }^{10}$, quando a ponta do cateter ficar perto do forame intervertebral, provocando parestesias, pode resultar em anestesia unilateral.

Concluindo, a dor, durante a punção raquidiana ou introdução do cateter peridural, é sinal de alarme. Pode indicar aguIha mal posicionada, ou desvio do cateter, com risco de lesão de uma estrutura nervosa, ou resultado insatisfatório do bloqueio.

\section{Pain during Spinal Canal Puncture and its Relationship with Ligamentum Flavum, Dura-Mater and Posterior Longitudinal Ligament Innervation}

\author{
Edmundo Zarzur, TSA, M.D.
}

\section{INTRODUCTION}

In addition to CSF, spinal space has nervous roots and the spinal cord. Ventral or motor root has its neurons in the gray matter of anterior funiculus medullae spinalis. These motor neurons form four or five rootlets in each spinal segment, which get together to form the anterior root, which after crossing the subarachnoid space perforates the dural sac and, involved by the dura, travels along dorsal root ganglion. Dorsal or sensory root has its neurons in the dorsal root ganglion, crosses the dura and the subarachnoid space to be divided, close to the spinal cord, into six rootlets before penetrating posterior funiculus medullae spinalis.

The conclusion is that these ventral and dorsal roots only travel in the subarachnoid space thus not being responsible for spinal canal structures innervation.
This study aimed at reviewing the innervation of structures involved in epidural and/or spinal puncture, calling the attention for potential complications when patients refer pain during the procedure.

\section{HISTORY}

Several investigators have studied spinal canal innervation. Ligamentum flavum is not innervated, explaining the lack of pain during its puncture ${ }^{1}$. Luschka, in 1850 , has described for the first time a recurrent meningeal branch currently known as being responsible for the innervation of several vertebral column structures ${ }^{2}$.

Luschka's nerve is the first branch originated from the spinal nerve. Soon after leaving intervertebral foramen, the spinal nerve supplies a first branch which crosses the intervertebral foramen and, returning to the canal, together with a communicating gray branch of the sympathetic nerve, is distributed through very thin filaments throughout the intervetebral disk, into anterior and posterior longitudinal ligaments and throughout the dural ventral portion.

Groen et al. have dissected vertebral column of different fetuses aiming at studying dural innervation. After removing thoracic meninges, nervous plexuses were stained and photographed by a transilumination process ${ }^{3}$.

They have observed that Luschka's recurrent nerve forms an extensive nervous plexus over posterior longitudinal ligament and over dural ventral portion, remaining the dorsal face of the dural sac without innervation. So, only ventral dura, dura involving nervous roots after leaving the dural sac and posterior longitudinal ligament receive sensory fibers supplied by Luschka's nerve (Figure 1).

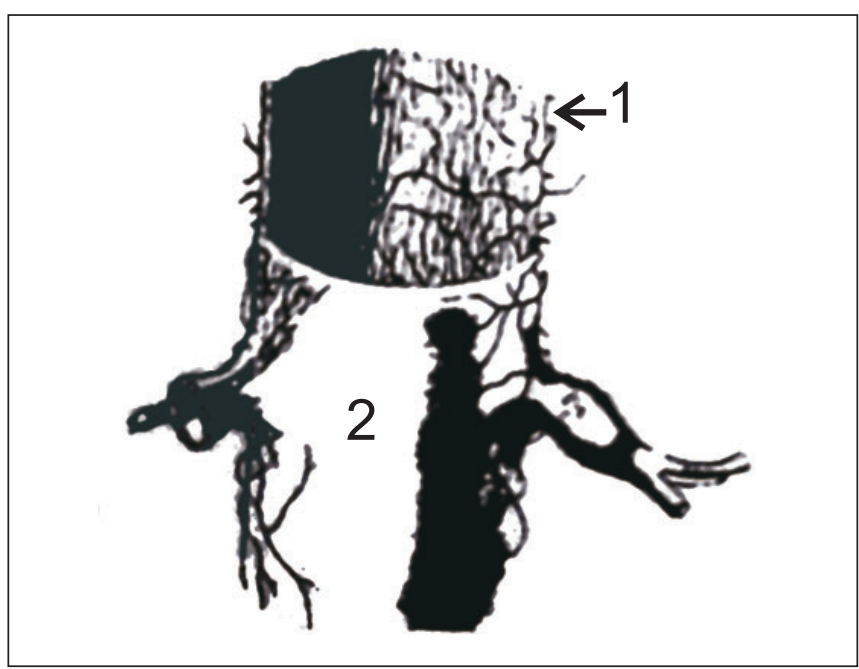

Figure 1 - Schematic showing Dura-Mater Innervation Dorsal view of the cylindric dural sac with its cuffs. 1 - Nervous plexus of dural ventral portion; 2 - Dural dorsal portion. Luschka's nerve branches and nervous plexus of posterior longitudinal ligament are not shown 
Dural dorsal face remains without innervation, thus explaining lack of pain during puncture. Raoul et al. ${ }^{4}$ have also studied the recurrent meningeal nerve of six fresh cadavers and three kept in formalin. Their observations however were directed to the lumbar region They have observed that Luschka's nerve together with a sympathetic communicating branch, would return to the canal to innervate intervertebral disk, dural ventral face and anterior and posterior longitudinal ligaments. They have concluded that back pain might be related to this innervation, and that epidural space infiltrations with anesthetic solutions could be used to relieve such pain.

Because ventral dura is innervated, Cyriax admits that its compression by a herniated disk may cause acute low back pain ${ }^{5}$. In this case, treatment with epidural anesthesia has a dramatic effect, relieving pain in few minutes.

It is clear that after dural perforation there might be low back pain caused by nervous roots injury, as well as thoracic pain, caused by direct spinal cord injury.

The conclusion is that pain referred during spinal puncture should be attributed to shift in the direction (medium sagital plane) the needle should follow. Pain may also appear during epidural block with single dose. Aiming at proving this thesis, Mondadore injected distilled water to confirm the exact location of the needle in the epidural space ${ }^{6}$. The injection of 3 to 4 $\mathrm{ml}$ distilled water in the epidural space would cause pain. This was the "Pain Test" considered by him more frequent than hanging-drop aspiration sign. This practice has been abandoned for causing very severe pain not tolerated by patients. However, distilled water injected in the subarachnoid space would not cause any pain or sensation. Mondadore has not found anatomic reasons for epidural space pain.

Zarzur et al. have observed that the "test dose", when performed with anesthetic solution with epinephrine, promotes perfectly tolerable pain ${ }^{7}$. This pain would be a confirmation of needle tip location in the epidural space. A second test dose would not cause pain. They have also observed that test-dose, when performed with epinephrine-free anesthetic solution would not cause pain. Pain could be possibly attributed to special dural sensitivity due to low $\mathrm{pH}$ of the anesthetic solution with epinephrine. By the time when the study about test-dose pain was published, we had no idea of the reason for the lack of pain during the second test-dose. With current knowledge, one may conclude that the first test-dose blocks nervous terminations justifying lack of pain during the second test-dose.

It should be reminded that paresthesias or pain during catheter introduction, by continuous epidural block technique, are evidences of poor catheter tip location, which may be touching nervous roots located in the antero-lateral epidural compartment, thus close to intervertebral foramina. Since current catheters do not perforate dura ${ }^{8}$ and, when introduced in the epidural space for 2 or more centimeters, they advance following dural sac curvature, they may reach the dorsal root located in the antero-lateral epidural compartment. In these cases, there might be a high incidence of failures or unilateral and unsatisfactory block. Hehre et al. ${ }^{9}$ have mentioned that 7 of 16 epidural block failures were preceded by paresthesias. For Sanches et al. ${ }^{10}$ when the catheter tip is close to the intervertebral foramen causing paresthesias, it may also result in unilateral anesthesia.

In conclusion, pain during spinal puncture or epidural catheter introduction is a warning. It may indicate poorly positioned needle or catheter deviation, with risk for nervous structure injury or unsatisfactory block.

\section{REFERÊNCIAS - REFERENCES}

01. Ramsey RH - The anatomy of the ligamenta flava. Clin Orthop 1966;44:129-140.

02. Luschka H von - Die nerven des menschlichen wirbelkanales. Tübingen: Laupp \& Siebeck, 1850:346-356.

03. Groen GJ, Baljet B, Drukker J - The innervation of the spinal dura mater: anatomy and clinical implications. Acta Neurochir (Wien), 1988;92:39-46.

04. Raoul S, Faure A, Robert R et al - Role of the sinu-vertebral nerve in low back pain and anatomical basis of therapeutic implications. Surg Radiol Anat, 2002;24:366-371.

05. Cyriax J - Dural pain. Lancet, 1978;21:919-921.

06. Mondadore ECF - Anestesia peridural. An Paul Med Cir, 1938;36-1.

07. Zarzur E, Saito K - A dor como comprovação da localização da agulha no espaço peridural. Rev Bras Anestesiol, 1979;4: 336-338.

08 . Hardy PA - Can epidural catheters penetrate dura mater? An anatomical study. Anaesthesia, 1986;41:1146-1147.

09. Hehre FW, Sayig JM, Lowman RM - Etiologic aspects of failure of continuous lumbar peridural anesthesia. Anesth Analg, 1960;39:511-517.

10. Sanchez R, Acuña L, Rocha F - An analysis of the radiological visualization of the catheters placed in the epidural space. $\mathrm{Br} \mathrm{J}$ Anaesth, 1967;39:485-489.

\section{RESUMEN}

Zarzur Y - El Dolor durante la Punción del Canal Vertebral y su Relación con la Inervación del Ligamento Amarillo, de la Dura-Máter y del Ligamento Longitudinal Posterior

JUSTIFICATIVA Y OBJETIVOS: El dolor durante la punción raquidiana es un señal de alarma, indicando que la punta de la aguja tocó en una estructura nerviosa. Por este motivo, si el paciente acusa dolor durante la punción, es obligatoria la interrupción de la técnica. La solución anestésica no deberá ser inyectada para evitar una posible lesión de la raíz nerviosa o de la médula espinal. Se debe retroceder la aguja y alterar su dirección antes de nuevo avance. El relato de dolor es totalmente imposible si el paciente está adormecido bajo influencia de la anestesia general y, por este motivo, es recomendable que bloqueos sean realizados con el paciente consciente. El dolor solamente es referido cuando la punta de la aguja o la punta del catéter se desvían del plano medio sagital para alcanzar el compartimiento peridural antero-lateral, pudiendo, de esta forma tocar las radículas nerviosas situadas próximas a los forames intervertebrales. Excluyéndose los estudios sobre la inervación de la piel, del tejido celular subcutáneo y del ligamento interespinoso, el objetivo de este 
trabajo es el de rever la inervación de algunas estructuras del canal vertebral: del ligamento amarillo, del ligamento longitudinal posterior, de la dura-máter y del disco intervertebral.

CONTENIDO: Estudios sobre la inervación del canal vertebral serán presentados en esta revisión de la literatura, con la intención de querer entender la razón del origen del dolor durante la punción del canal raquidiano.
CONCLUSIONES: El ligamento amarillo es desprovisto de inervación, explicando la ausencia de dolor durante su punción. Otros dolores, durante la punción, pueden ser atribuidos al nervio de Luschka que inerva el ligamento longitudinal posterior y la porción ventral de la dura-máter. 